\section{A) Check for updates}

Cite this: Dalton Trans., 2020, 49 2671

\title{
Appraisal of calcium ferrites as cathodes for calcium rechargeable batteries: DFT, synthesis, characterization and electrochemistry of $\mathrm{Ca}_{4} \mathrm{Fe}_{9} \mathrm{O}_{17 \dagger} \dagger$
}

\author{
Ashley P. Black, (D) ${ }^{a, b}$ Arturo Torres, ${ }^{c}$ Carlos Frontera, ${ }^{a, b}$ M. Rosa Palacín (D) ${ }^{a, b}$ and \\ M. Elena Arroyo-de Dompablo (iD *c
}

\begin{abstract}
Sustainability combined with high energy density prospects makes Fe-based oxides attractive as cathodes for calcium rechargeable batteries. This work presents a DFT evaluation of the $\mathrm{CaFe}_{2+n} \mathrm{O}_{4+n}(0<n<3)$ family, for which both the average intercalation voltage and the theoretical specific capacity decrease with the increasing $n$ value. The term $n=1 / 4, \mathrm{Ca}_{4} \mathrm{Fe}_{9} \mathrm{O}_{17}$, meets the most appealing characteristics: a calculated average voltage of $4.16 \mathrm{~V}$, a theoretical specific capacity of $230 \mathrm{~mA} \mathrm{~h} \mathrm{~g}^{-1}$ and the lowest energy barrier for Ca migration so far predicted for an existing oxide $(0.72 \mathrm{eV})$. To overcome the previously reported synthesis difficulties, we employed a novel synthesis procedure in sealed quartz tubes followed by quenching in water. The XRD and SAED patterns of the prepared $\mathrm{Ca}_{4} \mathrm{Fe}_{9} \mathrm{O}_{17}$ powder reveal a certain degree of stacking defects along the $c$ axis. Attempts to deinsert $\mathrm{Ca}$ ions from $\mathrm{Ca}_{4} \mathrm{Fe}_{9} \mathrm{O}_{17}$ by chemical means $\left(\mathrm{NO}_{2} \mathrm{BF}_{4}\right.$ in $\left.\mathrm{ACN}\right)$ and in electrochemical $\mathrm{Ca}$ cells were unsuccessful, although some hints of oxidation are observed in Li cells with the LP30 electrolyte. The suitability of $\mathrm{Ca}_{4} \mathrm{Fe}_{9} \mathrm{O}_{17}$ as a $\mathrm{Ca}$ cathode is pending further studies utilizing Ca-electrolytes with high anodic stability.
\end{abstract}

Received 9th December 2019 Accepted 20th January 2020

DOI: $10.1039 / \mathrm{c} 9 \mathrm{dt} 04688 \mathrm{~g}$ rsc.li/dalton calcium anodes (1340 $\left.\mathrm{mA} \mathrm{h} \mathrm{g}^{-1}\right)$ and its negative reduction potential (only $170 \mathrm{mV}$ above that of lithium metal). ${ }^{1,2}$ Advances in the development of such batteries are intricate due to the lack of competitive cathode materials and electrolytes. $^{3,4}$ While recent findings demonstrate the feasibility of $\mathrm{Ca}$ anode operation using different electrolytes, ${ }^{5-8}$ the identification of suitable cathode materials has been facing several roadblocks. ${ }^{4,9,10}$ Limited reversible electrochemical Ca intercalation has been reported for a handful of compounds ${ }^{4}$ $\left(\mathrm{V}_{2} \mathrm{O}_{5},{ }^{11} \mathrm{TiS}_{2},{ }^{12} \mathrm{MoO}_{3},{ }^{13} \mathrm{Ca}_{0.5} \mathrm{CoO}_{2},{ }^{14}\right.$ and manganese hexacyanoferrate ${ }^{1}$ ), all of them showing poor cycling, if any. Parallel experimental and computational investigations establish a link between the lack of reversible electrochemical activity (experimentally observed) and hampered Ca diffusion (computationally estimated). ${ }^{15-20}$ In this regard, the poor diffusion of $\mathrm{Ca}^{2+}$ in inorganic structures is the major challenge for cathode discovery. ${ }^{21}$ Compared to $\mathrm{Li}^{+}$diffusion, the hindrance to $\mathrm{Ca}$ mobility resides in the larger size of $\mathrm{Ca}^{2+}$ ions on one hand and its divalent charge on the other that increases the electrostatic repulsion/attraction with the neighbouring cations/ anions in the structure.

Sustainable cathode materials should include abundant and non-toxic elements, and at the same time, comply with the high energy density requirements. These criteria prompted the investigation of light and abundant oxidizing 3d-transition 
metal oxides as cathodes for Ca batteries. So far several $\mathrm{Mn}$ oxides and polyoxoanionic compounds have been reported, going from the virtual spinel $\mathrm{CaMn}_{2} \mathrm{O}_{4}{ }^{22}$ to the $\mathrm{CaMnO}_{3}$ perovskite, ${ }^{16}$ its reduced derivative $-\mathrm{Ca}_{2} \mathrm{Mn}_{2} \mathrm{O}_{5},{ }^{23}$ the known $\mathrm{CaMn}_{2} \mathrm{O}_{4}$ polymorphs (marokite and its high pressure form), ${ }^{15}$ a related oxidized phase, $\mathrm{CaMn}_{4} \mathrm{O}_{8},{ }^{23}$ and the minerals $\mathrm{K}_{0.31} \mathrm{MnO}_{2} \quad 0.25 \mathrm{H}_{2} \mathrm{O}$ (birnessite), ${ }^{24} \mathrm{Mg}_{0.19} \mathrm{Na}_{0.07} \mathrm{MnO}_{2} \quad 0.37 \mathrm{H}_{2} \mathrm{O}$ (todorokite), ${ }^{25} \mathrm{CaMn}\left(\mathrm{CO}_{3}\right)_{2}$ (kutnahorite) ${ }^{26}$ and $\mathrm{CaMnSi}_{2} \mathrm{O}_{6}$ (johannsenite). ${ }^{26}$ In contrast, research on Fe oxides has been scarce; the perovskite $\mathrm{CaFeO}_{3}$ and the related brownmillerite $\mathrm{Ca}_{2} \mathrm{Fe}_{2} \mathrm{O}_{5}$ compounds have been only evaluated by computational means. ${ }^{16,23}$ It was found that Ca-perovskites are not competitive materials due to hindered Ca mobility (a calculated energy barrier of $2 \mathrm{~V}$ ). ${ }^{16}$ In the brownmillerite structure the oxygen vacancies respective to the perovskite create a new pathway with much lower energy barrier $(1 \mathrm{eV}) .^{23}$ The present investigation turns to other known oxides in the $\mathrm{Ca}-\mathrm{Fe}-\mathrm{O}$ system with general formulae $\mathrm{CaFe}_{2+n} \mathrm{O}_{4+n}$ that might be worthy candidates (Fig. 1).

The crystal structure of $\mathrm{CaFe}_{2} \mathrm{O}_{4}$ (S.G. Pmna, no. 53) ${ }^{27,28}$ consists of edge-sharing chains of $\mathrm{MnO}_{6}$ octahedra, forming double rutile chains (see Fig. 1a). Each double-rutile chain is connected to two adjacent chains through edge-sharing oxygen. As a result, tunnels appear along the $b$ axis where $\mathrm{Ca}$ ions reside in eight-fold coordination. The calcium ferrite $\mathrm{CaFe}_{2+n} \mathrm{O}_{4+n}$ family is formed by stacking along the $c$ axis (S.G. Cmcm, no. 63) of blocks with the $\mathrm{CaFe}_{2} \mathrm{O}_{4}$ composition and blocks with the FeO composition (see Fig. 1b). Within this family, the compounds with $n=0,1,3 / 2,2,5 / 2$, and 3 have been reported. ${ }^{29,30}$ Interestingly, for $n=1 / 4$, the compound $\mathrm{Ca}_{4} \mathrm{Fe}_{9} \mathrm{O}_{17}$ crystallizes in a different structure (S.G. C2, no. 5), built up by layers of $\mathrm{Fe}$ atoms in edge-sharing $\mathrm{FeO}_{6}$ octahedra and vertex-sharing $\mathrm{Fe}$ in trigonal-based bipyramid coordination (see Fig. 1c and d). ${ }^{31}$ These hexagonal layers stack along the $c$-axis direction, being cross-linked by iron atoms in tetrahedral coordination. The $\left[\mathrm{FeO}_{4}\right]$-tetrahedra are connected in the $a b$ plane of the structure by hexa-coordinated $\mathrm{Ca}-\mathrm{O}$ polyhedra (Fig. 1d). The $\mathrm{CaO}_{6}$ distorted octahedra share edges forming rings around the $\mathrm{FeO}_{4}$-tetrahedra. Unsurprisingly, this structure with Fe in three different coordination environments, and in an average oxidation state of 2.888 , is thermodynamically quite unstable. ${ }^{32-34}$ The oxygen partial pressure is critical in the stability of $\mathrm{Ca}_{4} \mathrm{Fe}_{9} \mathrm{O}_{17}$, and therefore the complex synthesis of the material usually results in a mixture of a low crystalline $\mathrm{Ca}_{4} \mathrm{Fe}_{9} \mathrm{O}_{17}$ and more stable oxides $\left(\mathrm{CaFe}_{2} \mathrm{O}_{4}, \mathrm{FeO}\right.$, and $\mathrm{Ca}_{2} \mathrm{Fe}_{2} \mathrm{O}_{5}$ ). Indeed, the crystal structure determination was accomplished using single crystals grown under very specific conditions. $^{31}$

To evaluate the performance of $\mathrm{CaFe}_{2+n} \mathrm{O}_{4+n}$ compounds as cathode materials for $\mathrm{Ca}$ batteries, we have selected the compounds with $n=0,1 / 4,1$ and 2 for computational investigations. Density Functional Theory (DFT) calculations are used to anticipate the average intercalation voltage so as to estimate their theoretical energy density, assuming the full Ca extrac-
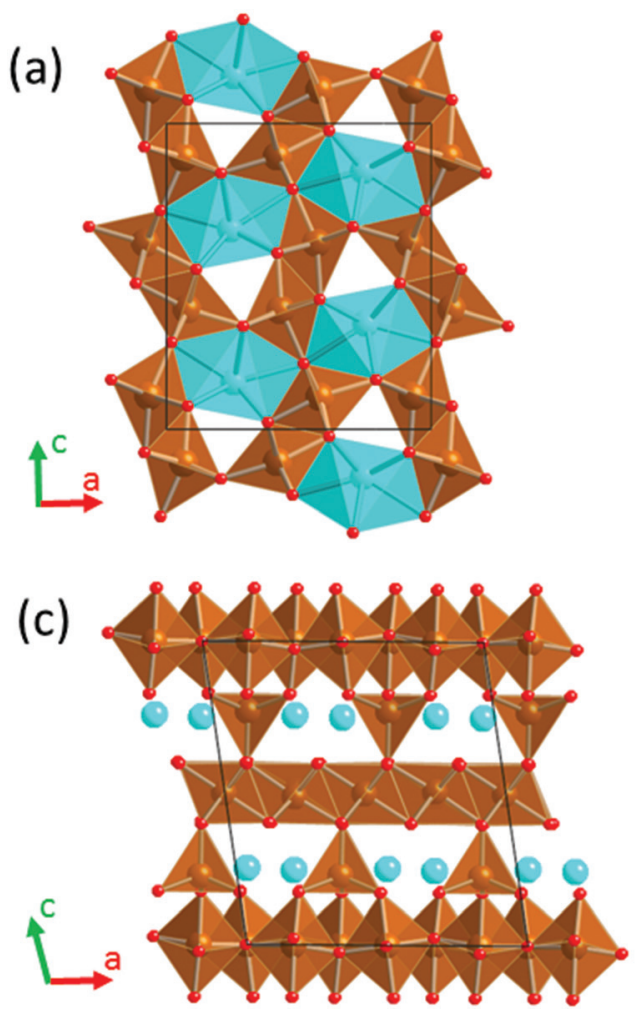

(b)
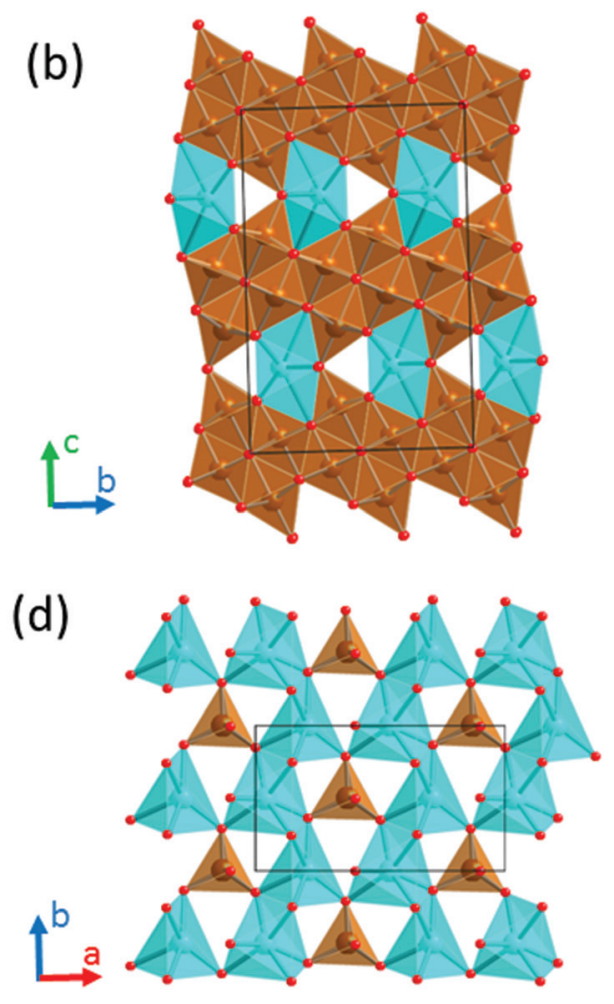

Fig. 1 Crystal structures of $\mathrm{CaFe}_{2+n} \mathrm{O}_{4+n}$ oxides. (a) $n=0, \mathrm{CaFe}_{2} \mathrm{O}_{4}$ (b) $n=2, \mathrm{CaFe}_{4} \mathrm{O}_{6}$ (c) $n=1 / 4, \mathrm{CaFe}_{9} \mathrm{O}_{17}$ showing the $\left[\mathrm{CaO}\right.$ ] $-\left[\mathrm{FeO} \mathrm{O}_{4}\right]$ plane in (d). Color code: $\mathrm{Ca}$ in blue, $\mathrm{Fe}$ in brown and $\mathrm{O}$ in red. 
tion from the structures. Ca diffusion is a key parameter, for which the migration energy barriers provide an approximate indication. ${ }^{3,35}$ Following vast literature in the field, ${ }^{18,21,22,35}$ in this work the energy barriers for Ca migration are extracted from DFT calculations. The results found for $\mathrm{Ca}_{4} \mathrm{Fe}_{9} \mathrm{O}_{17}$ motivated an experimental investigation comprising the synthesis, characterization and electrochemical testing of the material. We present a novel synthesis method to produce highly crystalline powder.

\section{Materials and methods}

\section{Computational}

The calculations have been carried out using the $a b$ initio total-energy and molecular dynamics program VASP (Vienna $a b$ initio simulation program) developed at the Universität Wien. ${ }^{36}$ Total energy calculations based on Density Functional Theory (DFT) were performed within the General Gradient Approximation (GGA), with the exchange and correlation functional form developed by Perdew, Burke and Ernzerhof (PBE). ${ }^{37}$ The interaction of core electrons with the nuclei is described by the Projector Augmented Wave (PAW) method. ${ }^{38}$ The energy cut off for the plane wave basis set is fixed at a constant value of $600 \mathrm{eV}$ throughout the calculations. The integration in the Brillouin zone is done on an appropriate set of $k$-points determined using the Monkhors-Pack scheme. A convergence of the total energy close to $10 \mathrm{meV}$ per formula unit is achieved with such parameters. Spin polarization calculations were performed in all cases. All crystal structures were fully relaxed (atomic positions, cell parameters and volume). The final energies of the optimized geometries were recalculated to correct the changes in the basis set of wave functions during relaxation. Average voltages for $\mathrm{Ca}$ deinsertion from $\mathrm{CaFe}_{2+n} \mathrm{O}_{4+n}$ were calculated within the GGA+U method, following the methodology described by Aydinol et al. ${ }^{39}$. For consistency with the literature on this topic, ${ }^{16,21,22,40}$ the effective $U$ value for the Fe-d orbitals was set to $5 \mathrm{eV}(J=1 \mathrm{eV})$.

Calcium mobility is investigated using the Nudged Elastic Band method (NEB) as implemented in VASP. To study diffusion, a vacancy is created in the structural model of the stoichiometric oxides and a simple jumping mechanism from an occupied position to the vacant site is considered. Supercells $1 \times 2 \times 1\left(\mathrm{Ca}_{8} \mathrm{Fe}_{18} \mathrm{O}_{34}\right)$ and $1 \times 4 \times 1\left(\mathrm{Ca}_{4} \mathrm{Fe}_{8} \mathrm{O}_{16}\right)$ for the $n=1 / 4$ and $n=0$ compounds, respectively, were used for the calculations. Constant volume calculations were performed within the GGA approximation for three or five intermediate images initialized by linear interpolation between the two fully relaxed end-points. To calculate the energy at the saddle point, cubic splines were fit through the relaxed images along each hop.

\section{Experimental}

Synthesis. Polycrystalline $\mathrm{Ca}_{4} \mathrm{Fe}_{9} \mathrm{O}_{17}$ powder samples were prepared by the conventional solid state synthesis method. Stoichiometric mixtures of $\mathrm{Ca}_{2} \mathrm{Fe}_{2} \mathrm{O}_{5}, \mathrm{Fe}_{2} \mathrm{O}_{3}$ and $\mathrm{Fe}_{3} \mathrm{O}_{4}$ in a molar ratio of $2: 1: 1$ were thoroughly mixed in an agate mortar, pressed into a pellet and vacuum sealed in a quartz tube. First the samples were thermally treated at $1000^{\circ} \mathrm{C}$ for $24 \mathrm{~h}$ and quenched in water. Then, the purest sample was obtained after four consecutive regrinding and annealing processes of $24 \mathrm{~h}$ each at $1150{ }^{\circ} \mathrm{C}$ in evacuated quartz tubes. $\mathrm{Ca}_{2} \mathrm{Fe}_{2} \mathrm{O}_{5}$ was previously synthesized following the Pechini method. $\quad \mathrm{Ca}\left(\mathrm{NO}_{3}\right)_{2} \cdot 4 \mathrm{H}_{2} \mathrm{O}$ (Aldrich 99\%), $\mathrm{Fe}\left(\mathrm{NO}_{3}\right)_{3} \cdot 9 \mathrm{H}_{2} \mathrm{O}$ (Aldrich 99.95\%), $\mathrm{C}_{6} \mathrm{H}_{8} \mathrm{O}_{7}$ (citric acid, Aldrich 99.5\%) and $\mathrm{C}_{2} \mathrm{H}_{6} \mathrm{O}_{2}$ (ethylene glycol) were subsequently dissolved in water in a molar ratio of $\mathrm{Ca}: \mathrm{Fe}: \mathrm{C}_{6} \mathrm{H}_{8} \mathrm{O}_{7}: \mathrm{C}_{2} \mathrm{H}_{6} \mathrm{O}_{2}=1: 1: 3: 1$. The solution was kept under continuous stirring at $80{ }^{\circ} \mathrm{C}$ until complete evaporation. The obtained citrate complexes were decomposed in air at $500{ }^{\circ} \mathrm{C}$ for $8 \mathrm{~h}$. The decomposition process was carried out at a rate of $100{ }^{\circ} \mathrm{C} \mathrm{h}^{-1}$. Finally, polycrystalline $\mathrm{Ca}_{2} \mathrm{Fe}_{2} \mathrm{O}_{5}$ was obtained by calcination of the amorphous carbonates at $1000^{\circ} \mathrm{C}$ for $24 \mathrm{~h}$.

Structural, morphological and compositional characterization. X-Ray powder diffraction patterns were acquired on a Bruker D8 Advance A25 diffractometer in a Debye Scherrer configuration equipped with an $M o K_{\alpha 1}$ radiation source. High resolution synchrotron X-ray diffraction (SXRD) patterns were collected in the MSPD beamline (ALBA synchrotron Light Source, Cerdanyola del Vallès, Spain $)^{41}$ using a Mythen detector and $\lambda=0.8260 \AA$. In both cases, $0.5 \mathrm{~mm}$ diameter borosilicate glass capillaries were used as sample holders and rotated during data collection.

Scanning Electron Microscopy (SEM) and Energy Dispersive X-ray Spectroscopy (EDS) analyses were performed by using a FEI Quanta 200 FEG microscope equipped with an EDAX detector (resolution: $132 \mathrm{eV}$ ). Selected Area Electron Diffraction (SAED) studies were performed using a JEOL 1210 transmission electron microscope operating at $120 \mathrm{kV}$ and equipped with a Gathan sample holder. The specimens for electron microscopy were prepared by dispersing the powders in dimethyl carbonate and depositing a droplet of this suspension on a carbon coated film supported on a copper grid.

Electrochemical tests. Electrode tapes were prepared by dispersing a powder mixture of the active material (80 wt\%), Super $\mathrm{P}$ carbon (10 wt\%) and a polyvinylidene difluoride (PVdF, Kynar) binder (10 wt\%) in $N$-methyl pyrrolidinone solvent (NMP, Sigma-Aldrich). The obtained dispersion was ball milled for 1 hour at $500 \mathrm{~Hz}$ with a RETSCH PM100 instrument before being doctor-blade cast on Al foil (Goodfellow, 99\%). Once cast, the tapes were dried under vacuum and cut into discs of $11 \mathrm{~mm}$ diameter, with an average active material load of about $2 \mathrm{mg}$. The electrodes were pressed at 5 Tons before being used.

The electrochemical tests were run in two and three electrode Swagelok cells assembled in an Ar-filled dry box, employing $\mathrm{Al}$ and stainless steel current collectors for the working and reference (RE)/counter (CE) electrodes, respectively, and a Whatman separator soaked in $0.6 \mathrm{ml}$ of electrolyte solution. Mechanically polished Ca metal discs (obtained by pressing Ca pieces under an inert atmosphere) or Li metal were used as the counter/reference or counter electrodes, respectively. 
Lithium hexafluorophosphate solutions in ethylene carbonate (EC) and dimethyl carbonate (DMC) (LP30, 1.0 M LiPF6 in $\mathrm{EC} / \mathrm{DMC}=50 / 50(\mathrm{v} / \mathrm{v})$, Solvionic) and the lithium bis(oxalato) borate salt (LiBoB, Chemetal, Battery grade) in a 1:1 v/v mixture of ethylene carbonate (EC) and propylene carbonate (PC) solvents (Solvionic, 99.9\%) were used as electrolytes for the electrochemical tests in Li cells. The electrolyte used in $\mathrm{Ca}$ cells was a dry ( $<40 \mathrm{ppm} \mathrm{H}_{2} \mathrm{O}$, Karl-Fischer titration) $0.45 \mathrm{M}$ calcium tetrafluoroborate hydrate (Alfa Aesar) solution in EC/ $\mathrm{PC}=50 / 50(\mathrm{v} / \mathrm{v})$.

The electrochemical tests were performed on a Bio-Logic VMP3 potentiostat. Electrochemical deintercalation/intercalation tests were carried out in galvanostatic mode (i.e. Galvanostatic Cycling with Potential Limitation-GCPL). In order to avoid kinetic limitations the rate was set to $\mathrm{C} / 100$. A stabilization time of 5 hours at the OCV was applied before each measurement was carried out at $100{ }^{\circ} \mathrm{C}$. Once tested, the cells were disassembled in an Ar-filled dry box and the electrodes were washed with dimethyl carbonate solvent (DMC, Sigma-Aldrich, $\geq 99 \%$ ) and further collected in borosilicate glass capillaries of $0.5 \mathrm{~mm}$ diameter for ex situ XRD measurements.

Chemical oxidation tests. Chemical oxidation tests were performed by dispersing the active material in an $\mathrm{NO}_{2} \mathrm{BF}_{4}$ solution in acetonitrile $(\mathrm{ACN})$ in a molar ratio of $1: 8$. The dispersion was kept under reflux at $80{ }^{\circ} \mathrm{C}$ for 6 hours. Uninterrupted Ar bubbling served to maintain the reaction atmosphere inert and to eliminate the $\mathrm{NO}_{2}$ gas formed as the byproduct. Once the reactions were completed, the samples were washed with dry ACN, vacuum filtered, dried and collected for XRD analysis.

\section{Results and discussion}

\section{DFT evaluation of basic electrode characteristics}

The GGA+U method correctly reproduces the cell lattice parameters of $\mathrm{CaFe}_{2+n} \mathrm{O}_{4+n}$ compounds (see Table $\mathrm{S} 1 \dagger$ ). The deinsertion of $\mathrm{Ca}$ can be expressed by the reaction:

$$
\mathrm{CaFe}_{2+n} \mathrm{O}_{4+n} \rightarrow \mathrm{Fe}_{2+n} \mathrm{O}_{4+n}+\mathrm{Ca}
$$

The higher the $n$ term, the lower the theoretical specific capacity is. These values are listed in Table 1 , together with the average voltage predicted for $n=0,1 / 4,1$ and 2. As $n$ increases the Fe ions are in a lower oxidation state, and accordingly $\mathrm{Ca}$ deinsertion is predicted at lower voltages. Note that the average voltage depends primarily on the redox couple, but it is also influenced by the crystal structure. ${ }^{39}$ For instance, the voltages predicted for the $\mathrm{Fe}^{3+} / \mathrm{Fe}^{4+}$ couple are $4.16 \mathrm{~V}$ in brownmillerite- $\mathrm{Ca}_{2} \mathrm{Fe}_{2} \mathrm{O}_{5}$ (ref. 23) and $3.87 \mathrm{~V}$ in $\mathrm{CaFe}_{2} \mathrm{O}_{4}$. Taking the calculated voltage and the theoretical specific capacities into account, theoretical energy densities exceeding $600 \mathrm{~mA} \mathrm{~h} \mathrm{~g}{ }^{-1}$ (the state of the art in the Li-ion technology) could be viable for $n=0,1 / 4$ and 1 .

One of the major concerns in cathode material design for the $\mathrm{Ca}$ battery technology is the mobility of $\mathrm{Ca}^{2+}$ ions in inorganic structures. Although other factors can certainly limit the success of $\mathrm{Ca}$ battery cathodes, a good cation diffusion, that is to say a low migration energy barrier, is a necessary prerequisite. It has been estimated that for a reasonable cell power rate (discharging time 2 hours) the energy barriers for cation diffusion should be below $0.525 \mathrm{eV}$ in micrometer particles and $0.65 \mathrm{eV}$ in nanosized-particles. ${ }^{3}$ The calculated energy barrier for $\mathrm{CaFe}_{2} \mathrm{O}_{4}(1.2 \mathrm{eV}$, see Fig. 1 in the ESI $\dagger)$ greatly surpasses this tolerable value, and therefore, the ferrites $\mathrm{CaFe}_{2+n} \mathrm{O}_{4+n}$ built up from $\mathrm{CaFe}_{2} \mathrm{O}_{4}$ blocks will also suffer from poor Ca mobility. However, the $n=1 / 4$ term might be a viable option. Fig. 2 shows the pathway for $\mathrm{Ca}$ diffusion in $\mathrm{Ca}_{4} \mathrm{Fe}_{9} \mathrm{O}_{17}$ and the calculated energy barrier. In the two-dimensional diffusion pathway in the $\left[\mathrm{CaO}_{6}\right]-\left[\mathrm{FeO}_{4}\right]$ plane (shown in Fig. 1d) the diffusing $\mathrm{Ca}$ ions exit from their polyhedra across a triangular face to occupy the intermediate tetrahedral site (see Fig. 2a). The associated energy barrier for in-plane $\mathrm{Ca}$ diffusion is $0.72 \mathrm{eV}$ (Fig. 2b), the lower energy ever reported for an existing transition metal oxide. The tetrahedral site represents a local energy minimum in the energy landscape. The similarity in $\mathrm{Ca}-\mathrm{Fe}$ distances at this intermediate site and at the equilibrium sites (3.22 $\AA$ and $3.29 \AA$, respectively) suggests that the diffusing $\mathrm{Ca}$ ion does not experience large electrostatic repulsions with the neighbouring $\mathrm{Fe}^{+2.88}$ cations. Compared to other oxides, the lower repulsive forces between the diffusing $\mathrm{Ca}^{2+}$ and other cations in the structure reduce the migration energy. ${ }^{4}$ Although the barrier is relatively low for Ca diffusion, it is still too high for fast rate performance. Note that the barriers for Li diffusion in layered, olivine and spinel cathodes are below $0.3 \mathrm{eV}^{3,35,42,43}$

Interestingly, a related compound, $\mathrm{K}_{2} \mathrm{Fe}_{4} \mathrm{O}_{7}$, has been recently reported and suggested as a K-superionic conductor. ${ }^{44}$ The framework of $\mathrm{K}_{2} \mathrm{Fe}_{4} \mathrm{O}_{7}$ consists of planes of edge-sharing $\mathrm{FeO}_{6}$ octahedra sandwiched between planes of $\mathrm{FeO}_{4}$ tetrahedra and octahedrally coordinated $\mathrm{K}$ ions. The $\mathrm{K}$ octahedra form rings around $\mathrm{FeO}_{4}$ tetrahedra, thus providing a $2 \mathrm{D}$ conduction plane similar to that in $\mathrm{Ca}_{4} \mathrm{Fe}_{9} \mathrm{O}_{17}$ (Fig. 1d and 2a). When tested in the $\mathrm{K} / \mathrm{K}_{2} \mathrm{Fe}_{4} \mathrm{O}_{7} / \mathrm{Pt}$ cell no significant current due to

Table 1 Electrode characteristics of $\mathrm{CaFe}_{2+n} \mathrm{O}_{4+n}$ assuming full $\mathrm{Ca}$ deinsertion (reaction 1)

\begin{tabular}{|c|c|c|c|c|c|}
\hline $\begin{array}{l}\mathrm{CaFe}_{2+n} \mathrm{O}_{4+n} \\
\text { composition }\end{array}$ & $n$ & $\begin{array}{l}\text { Fe redox } \\
\text { couple }\end{array}$ & $\begin{array}{l}\text { Theoretical specific capacity } \\
\left(\mathrm{mA} \mathrm{h}^{-1}\right)\end{array}$ & $\begin{array}{l}\text { Calculated average } \\
\text { voltage }(\mathrm{V})\end{array}$ & 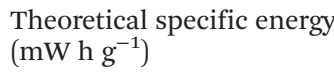 \\
\hline $\mathrm{CaFe}_{2} \mathrm{O}_{4}$ & 0 & $+3 /+4$ & 249 & 3.87 & 964 \\
\hline $\mathrm{CaFe}_{3} \mathrm{O}_{5}$ & 1 & $+2.66 /+3.33$ & 186 & 3.66 & 680 \\
\hline $\mathrm{CaFe}_{4} \mathrm{O}_{6}$ & 2 & $+2.5 /+3$ & 149 & 2.37 & 353 \\
\hline
\end{tabular}




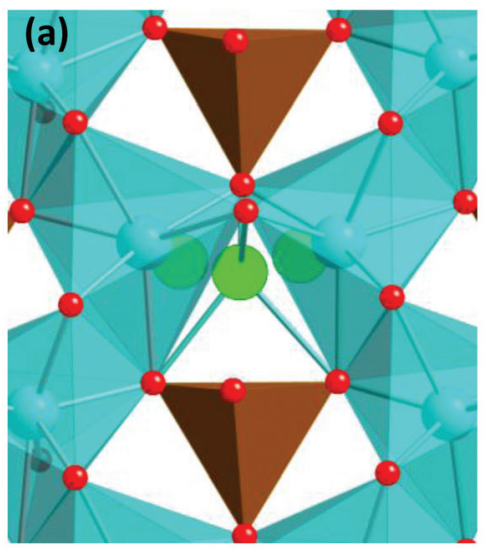

(b)

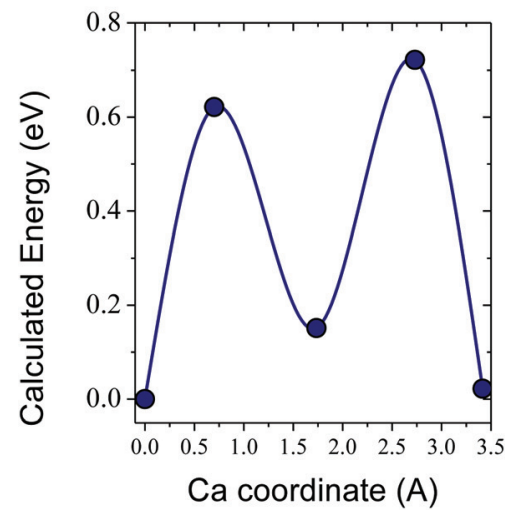

Fig. 2 (a) View of the $\mathrm{Ca}$ diffusion pathway in $\mathrm{Ca}_{4} \mathrm{Fe}_{9} \mathrm{O}_{17}$, showing the tetrahedral site at the transition state. (b) Calculated energy barrier. Color code: $\mathrm{Ca}$ sites in blue, diffusing $\mathrm{Ca}$ in green, $\mathrm{Fe}$ in brown, $\mathrm{O}$ in red.

the solid electrolyte decomposition was observed up to 5.0 V. Despite the presence of $\mathrm{Fe}^{3+}$, the authors found that the material is also stable upon reduction down to $0 \mathrm{~V}$.

\section{Synthesis}

$\mathrm{Ca}_{4} \mathrm{Fe}_{9} \mathrm{O}_{17}$ was first reported by B. Malaman et al. in the 80's ${ }^{31}$ and its crystal structure was elucidated from a single crystal. Despite a few articles mentioning its existence (a summary of those is provided in Table S2 $\dagger$ ), no reliable bulk powder synthesis method is available in the literature. In all cases, this phase is reported to form, mixed with $\mathrm{CaFe}_{2} \mathrm{O}_{4}$ and $\mathrm{Ca}_{2} \mathrm{Fe}_{2} \mathrm{O}_{5}$ phases that are stable in the same region of the $\mathrm{FeO}-\mathrm{Fe}_{3} \mathrm{O}_{4}-$ $\mathrm{CaO}$ phase diagram.

In view of the discrepancies present in the literature, in this work different synthesis methods were attempted at temperatures ranging from 800 to $1200{ }^{\circ} \mathrm{C}$, including conventional solid state synthesis using $\mathrm{CaCO}_{3}$ or $\mathrm{CaO}$ as $\mathrm{Ca}$ sources and $\mathrm{Fe}_{2} \mathrm{O}_{3}, \mathrm{Fe}_{3} \mathrm{O}_{4}$ or $\mathrm{FeO}$ as iron precursors. The Pechini method was also attempted. ${ }^{45}$ Most reaction products consisted of a mixture of $\mathrm{Fe}_{2} \mathrm{O}_{3}$ and $\mathrm{CaFe}_{2} \mathrm{O}_{4}$ in all cases, whatever the reaction times (from 6 to 64 hours), except for the samples treated at $1200{ }^{\circ} \mathrm{C}$ for which melting and thermal reduction of iron oxide was observed. Further synthesis attempts were carried out in a tube sealed under vacuum, and the phase $\mathrm{Ca}_{4} \mathrm{Fe}_{9} \mathrm{O}_{17}$ was observed in small amounts after synthesis at $1000^{\circ} \mathrm{C}$ for $48 \mathrm{~h}$ followed by quenching. Optimization of this reaction protocol, modifying precursors, temperature and time, enabled the synthesis of pure $\mathrm{Ca}_{4} \mathrm{Fe}_{9} \mathrm{O}_{17}$ using a stoichiometric mixture of $\mathrm{Ca}_{2} \mathrm{Fe}_{2} \mathrm{O}_{5}, \mathrm{Fe}_{2} \mathrm{O}_{3}$ and $\mathrm{Fe}_{3} \mathrm{O}_{4}$ as precursors, targeting to control the iron oxidation state by tuning the amount of oxygen available in the precursors. However, a pure phase was achieved only after several treatments at $1150{ }^{\circ} \mathrm{C}$ for $24 \mathrm{~h}$ each in a sealed quartz tube followed by quenching in water (a summary of synthesis results is provided in Fig. $\mathrm{S} 2 \dagger)$.

\section{Structure and morphology}

Fig. 3 shows a full pattern matching of X-ray diffraction patterns of the as prepared $\mathrm{Ca}_{4} \mathrm{Fe}_{9} \mathrm{O}_{17}$ sample in the monoclinic system, space group $C 2$ using the Fullprof program. The cell parameters obtained by the Le Bail method were $a=10.44177$ (24) $\AA$, $b=6.02422(21) \AA, c=11.36840(36) \AA$ and $\beta=98.7853$ (16) which are in good agreement with those previously reported from the single crystal structural determination. ${ }^{31}$

Attempts to perform a Rietveld refinement of this X-ray diffraction pattern using the structural model reported by B. Malaman et $a .^{31}$ resulted in unsatisfactory fitting of the model to the experimental pattern, despite all efforts to modify cell parameters, occupation factors, etc. The differences in the observed and calculated integrated intensities of several reflections suggest that the prepared material might present some structural differences with respect to the single crystal studied by B. Malaman (see Fig. S3†).

In order to further characterize the structure of the as prepared $\mathrm{Ca}_{4} \mathrm{Fe}_{9} \mathrm{O}_{17}$ phase, SAED was performed and micrometric particles were observed, as shown in Fig. 4. The cell parameters obtained by electron diffraction were $a=10.4 \AA, b=$ $6.02 \AA$ and $c=11.4 \AA$. The ED image along the $c$ zone axis presents the characteristic scattered lines indicative of the presence of stacking defects along the $c$ axis. The occurrence of stacking faults could explain the differences between observed

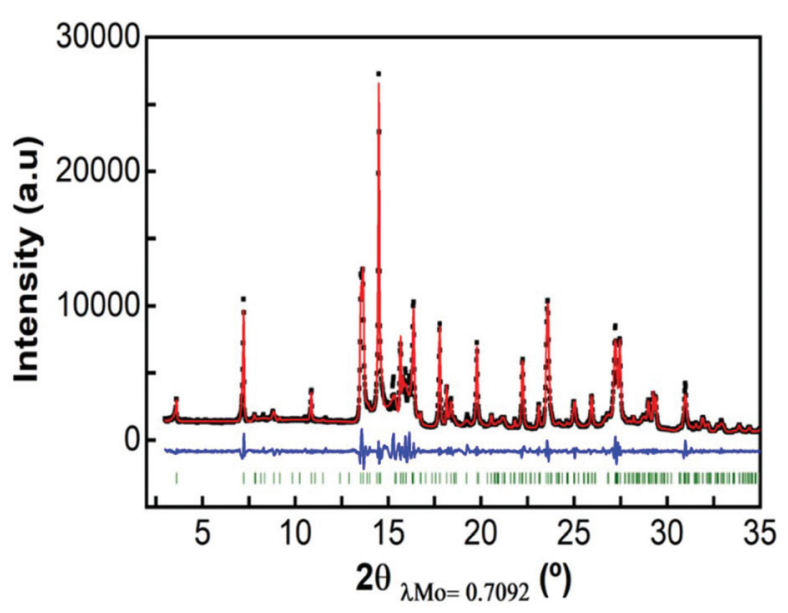

Fig. 3 Pattern matching of $\mathrm{Ca}_{4} \mathrm{Fe}_{9} \mathrm{O}_{17}$ in the monoclinic system, space group C2. 

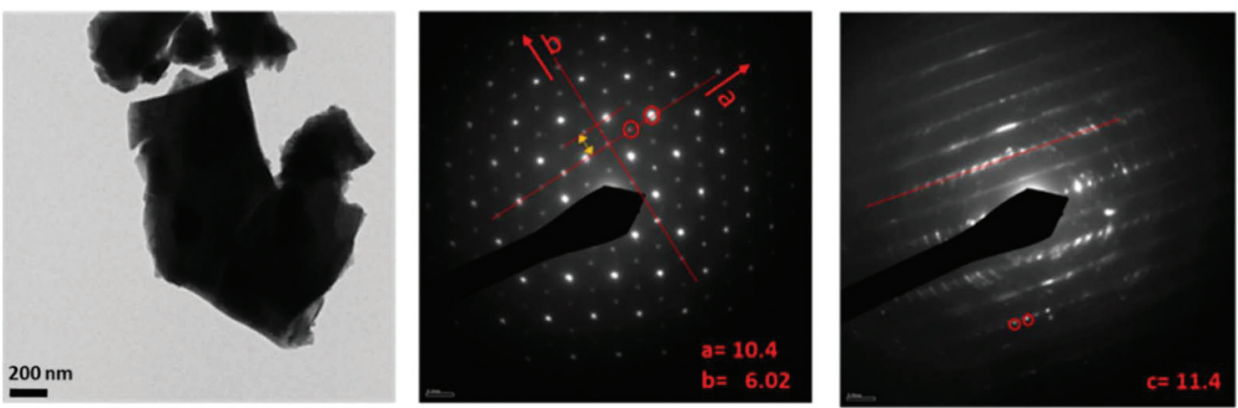

Fig. 4 SAED images of the $\mathrm{Ca}_{4} \mathrm{Fe}_{9} \mathrm{O}_{17}$ sample.

and calculated intensities in Rietveld refinement. The stacking faults are not expected to perturb the in-plane Ca conductivity, unless they imply inter-layer cation mixing or phase transformations. ${ }^{42,46}$

\section{Chemical and electrochemical tests on $\mathrm{Ca}_{4} \mathrm{Fe}_{9} \mathrm{O}_{17}$ and} $\mathrm{Ca}_{2} \mathrm{Fe}_{2} \mathrm{O}_{5}$

Attempts to extract $\mathrm{Ca}^{2+}$ from $\mathrm{Ca}_{4} \mathrm{Fe}_{9} \mathrm{O}_{17}$ were carried out both by chemical oxidation with $\mathrm{NO}_{2} \mathrm{BF}_{4}$ (ref. 47) and by electrochemical methods at room temperature and $100{ }^{\circ} \mathrm{C}$. Tape electrodes were prepared and cycled according to the electrochemical protocol described in the experimental section. The characteristic potential $v s$. capacity profiles of these electrodes upon galvanostatic cycling at $\mathrm{RT}$ and $100{ }^{\circ} \mathrm{C}$ in $\mathrm{Li}$ or Ca cells and in several $\mathrm{Li}$ or $\mathrm{Ca}$ electrolytes at $\mathrm{C} / 100$ are shown in Fig. 5 (a and b) for $\mathrm{Ca}_{4} \mathrm{Fe}_{9} \mathrm{O}_{17}$ and in Fig. $\mathrm{S} 4 \dagger$ (left panel) for $\mathrm{Ca}_{2} \mathrm{Fe}_{2} \mathrm{O}_{5}$. The utilization of a low rate $(\mathrm{C} / 100)$ is in line with the calculated energy barrier of $0.72 \mathrm{eV}$, which as commented before is too high for fast-rate performance. Indeed, Ca intercalation in $\mathrm{TiS}_{2}$ (calculated energy barrier $0.75 \mathrm{eV}$ ) requires similarly slow rates. ${ }^{12}$ Upon oxidation, a short plateau-like region centered between $2.9 \mathrm{~V}$ and $4.8 \mathrm{~V}$ vs. $\mathrm{M}^{n+} / \mathrm{M}(\mathrm{M}=\mathrm{Li}$ or $\mathrm{Ca}$ ) is observed, with the potential at which the plateau appears depending on the nature of the electrolyte, the temperature and the counter electrode used. The ex situ X-ray powder diffraction patterns of the $\mathrm{Ca}_{4} \mathrm{Fe}_{9} \mathrm{O}_{17}$ samples collected
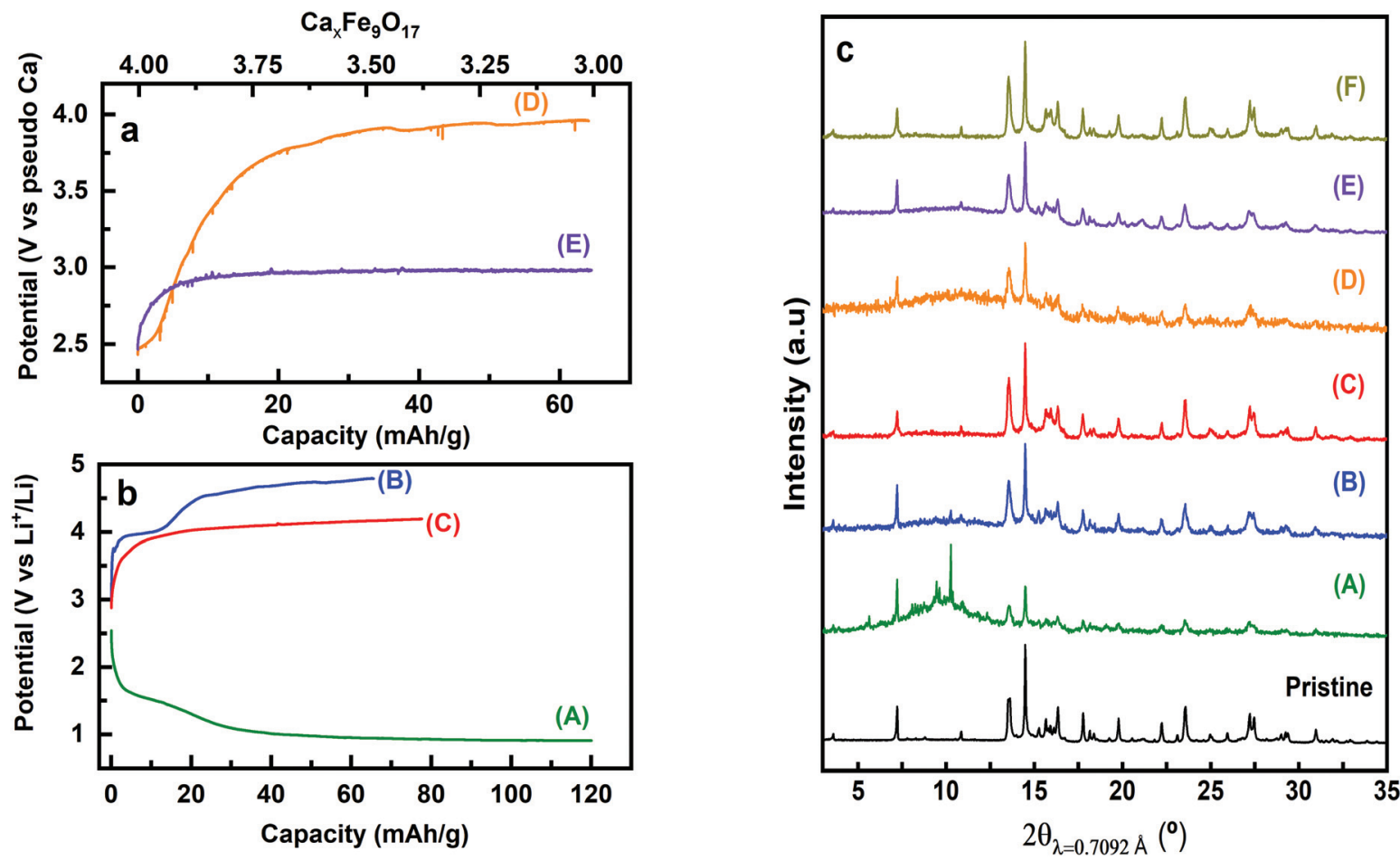

Fig. 5 Characteristic voltage profiles versus specific capacity (bottom) and versus moles of virtually de-inserted Ca ${ }^{2+}(\Delta x$, estimated that calcium deintercalation is the only reaction taking place) (top) for $\mathrm{Ca}_{4} \mathrm{Fe}_{9} \mathrm{O}_{17}$ in Ca cells (a), with $0.45 \mathrm{M} \mathrm{Ca}(\mathrm{BF})_{2}$, EC/PC (1:1 vol) electrolyte at RT (D) and $100{ }^{\circ} \mathrm{C}(\mathrm{E})$ and in Li cells (b), with LP30 electrolyte at RT (A and B), $1 \mathrm{~m}$ LiBOB, EC/PC (1:1 vol) electrolyte at $100{ }^{\circ} \mathrm{C}(\mathrm{C})$. Corresponding ex situ XRD patterns in (c). XRD patterns of the pristine and chemically oxidized samples (F) are also displayed in (c). 


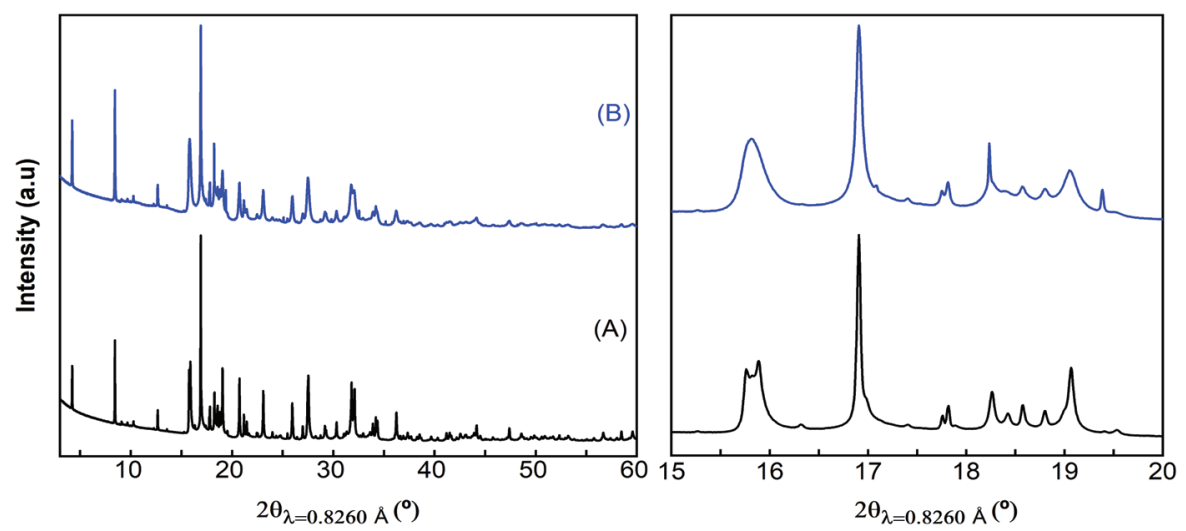

Fig. 6 Synchrotron X-ray powder diffraction patterns of pristine (A) and electrochemically oxidized (in the $\mathrm{LP}_{30}$ electrolyte) $(\mathrm{B}) \mathrm{Ca}_{4} \mathrm{Fe}_{9} \mathrm{O}_{17} \mathrm{samples}$

after the electrochemical and chemical oxidation tests are shown in Fig. 5(c) and Fig. $\mathrm{S} 4 \dagger$ (right panel), respectively. Compared with the pristine phase, neither peak shifts nor formation of extra phases is observed in any spectra except for the one corresponding to electrochemical measurement performed on $\mathrm{Ca}_{4} \mathrm{Fe}_{9} \mathrm{O}_{17}$ in the lithium cell with the LP30 electrolyte. Thus, except for that case, the electrochemical capacity observed is ascribed to side reactions most likely involving electrolyte decomposition, which are enhanced at high temperature. In contrast, the synchrotron X-ray diffraction patterns of the pristine sample and the sample electrochemically oxidized in a lithium/LP30 cell exhibit minor differences (see Fig. 6). Indeed, the pattern full width at half maximum for peaks situated at Q values of $2.09 \AA^{-1}, 2.24 \AA^{-1}$ and $2.53 \AA^{-1}$ is different.

While the origin of these subtle changes has been unclear to date, one may speculate that they could be related to deinsertion of a small amount of calcium from $\mathrm{Ca}_{4} \mathrm{Fe}_{9} \mathrm{O}_{17}$ at the $4.0 \mathrm{~V}$ plateau (capacity $12 \mathrm{~mA} \mathrm{~h} \mathrm{~g}{ }^{-1}$, curve B in Fig. $5 \mathrm{~b}$ ) concomitant with the oxidation of iron. In fact, hypothetical oxidation to yield $\mathrm{Ca}_{3.5} \mathrm{Fe}_{9} \mathrm{O}_{17}$ could be related to the $\mathrm{Fe}^{2+} / \mathrm{Fe}^{3+}$ redox pair, with an expected voltage considerably smaller than $4.16 \mathrm{~V}$, and thus within the voltage window of the LP30 electrolyte stability. Further oxidation should involve the $\mathrm{Fe}^{3+} / \mathrm{Fe}^{4+}$ couple, with a higher voltage ( $c a .4 .2 \mathrm{~V}$ ), which may be out of the voltage window of the electrolyte stability, especially if polarization is significant. Yet, in light of the low value of the capacity and the disorder present in the crystals, this phenomenon has not been further studied.

Regardless of the partial oxidation of Fe detected in Li cells (likely the $\mathrm{Fe}^{2+} / \mathrm{Fe}^{3+}$ couple), further oxidation has not been achieved either electrochemically or chemically. Noteworthily, the calculated average voltage for the full Ca deinsertion, the $\mathrm{Fe}^{+2.88} / \mathrm{Fe}^{+3.77}$ couple (4.16 V, see Table 1 ), is probably beyond the anodic stability of available Ca electrolytes ${ }^{5}$ and in the limit of Li electrolytes if cell polarization is significant. In this regard, we attempted the electrochemical and chemical oxidation of $\mathrm{Ca}_{2} \mathrm{Fe}_{2} \mathrm{O}_{5}$, for which DFT investigations found an average voltage of $4.16 \mathrm{~V}$ for the $\mathrm{Fe}^{3+} / \mathrm{Fe}^{4+}$ couple, although with a sluggish kinetics (calculated energy migration barrier 1 eV). ${ }^{23}$ The combination of electrochemical and XRD characterization (see Fig. 3 in the ESI $\dagger$ ) reflects the inactivity of $\mathrm{Ca}_{2} \mathrm{Fe}_{2} \mathrm{O}_{5}$ in both $\mathrm{Ca}$ and $\mathrm{Li}$ electrolytes. A plausible explanation is that $\mathrm{Ca}$ deintercalation from these materials requires electrolytes operating in the $5 \mathrm{~V}$ range, so as to allow the oxidation of $\mathrm{Fe}$ to the +4 oxidation state.

To test the electrochemical stability window of $\mathrm{Ca}_{4} \mathrm{Fe}_{9} \mathrm{O}_{17}$, $\mathrm{Li} / \mathrm{LP} 30 / \mathrm{Ca}_{4} \mathrm{Fe}_{9} \mathrm{O}_{17}$ cells were discharged down to $1 \mathrm{~V}$. Upon reduction, the potential $v$ s. capacity profiles for $\mathrm{Ca}_{4} \mathrm{Fe}_{9} \mathrm{O}_{17}$ displayed in Fig. $5 \mathrm{~b}(\mathrm{~A})$ present a long plateau-like region centered at $1 \mathrm{~V} v s . \mathrm{Li}^{+} / \mathrm{Li}$ and additional diffraction peaks are observed in the $2 \theta=10^{\circ}$ region of the corresponding ex situ X-ray powder diffraction pattern shown in Fig. $5 \mathrm{c}(\mathrm{A})$. This large capacity can be regarded as the combination of two competing processes: the low-voltage decomposition of the electrolyte and the reduction of $\mathrm{Fe}^{3+}$ to $\mathrm{Fe}^{2+}$ upon $\mathrm{Li}$ uptake. Noteworthily, a similar potential vs. capacity profile is observed for the reduction of $\mathrm{Fe}_{2} \mathrm{O}_{3}$ electrodes in Li cells; ${ }^{48}$ the electrochemical conversion reactions of $\mathrm{Fe}^{3+}$ compounds with lithium are known to evolve until the eventual formation of small $\mathrm{Li}_{2} \mathrm{O}$ and metallic iron domains. ${ }^{48,49}$ In the present case, the identification of the phases formed during the reduction remains undetermined due to the complex nature of the starting material. However, these results highlight the instability of $\mathrm{Ca}_{4} \mathrm{Fe}_{9} \mathrm{O}_{17}$ upon reduction, contrary to the reported stability of the related K-phase down to $0 \mathrm{~V} v s . \mathrm{K}^{+} / \mathrm{K}^{44}$

\section{Conclusions}

Sustainability combined with high energy density prospects makes Fe-based oxides appealing cathodes for calcium rechargeable batteries. The present DFT investigation reveals that among the $\mathrm{CaFe}_{2+n} \mathrm{O}_{4+n}$ materials, $\mathrm{Ca}_{4} \mathrm{Fe}_{9} \mathrm{O}_{17}$ combines the most appealing characteristics. The favorable local topology for $\mathrm{Ca}$ diffusion in $\mathrm{Ca}_{4} \mathrm{Fe}_{9} \mathrm{O}_{17}$ bestows the lowest energy barrier so far reported for an existing oxide $(0.72 \mathrm{eV})$. However, the predicted average deintercalation voltage $(4.16 \mathrm{~V}$ for full $\mathrm{Ca}$ 
deinsertion) is beyond the stability range of current Ca electrolytes and, accordingly, electrochemical attempts to deintercalate $\mathrm{Ca}$ ions from $\mathrm{Ca}_{4} \mathrm{Fe}_{9} \mathrm{O}_{17}$ in $\mathrm{Ca}$ cells were unsuccessful. However, a small charge capacity probably associated with the oxidation of $\mathrm{Fe}^{2+}$ to $\mathrm{Fe}^{3+}$ is observed in Li cells using the LP30 electrolyte. The suitability of $\mathrm{Ca}_{4} \mathrm{Fe}_{9} \mathrm{O}_{17}$ as a $\mathrm{Ca}$ cathode is pending further studies utilizing electrolytes with higher anodic stability. Electrochemical and any other property investigations will no doubt benefit from the novel synthesis route reported here which, contrary to previous strategies, allows synthesizing pure and crystalline $\mathrm{Ca}_{4} \mathrm{Fe}_{9} \mathrm{O}_{17}$ powders.

\section{Conflicts of interest}

There are no conflicts to declare.

\section{Acknowledgements}

This research was funded by the European Union's Horizon 2020 research and innovation programme H2020 FETOPEN-12016-2017 (CARBAT, grant agreement no. 766617). The authors are grateful for access to the computational facilities from Universidad de Oviedo (MALTA-Consolider cluster), to ALBA synchrotron for the provision of beam time and to Dr F. Fauth for his help during data collection and also acknowledge Dr. J. Oró-Solé for assistance with electron diffraction and Dr. Clemens Ritter for helpful discussions. ICMAB authors are also grateful to the Spanish Ministry for Economy, Industry and Competitiveness Severo Ochoa Programme for Centres of Excellence in R\&D (SEV-2015-0496).

\section{Notes and references}

1 A. L. Lipson, B. Pan, S. H. Lapidus, C. Liao, J. Y. Vaughey and B. J. Ingram, Chem. Mater., 2015, 27, 8442-8447.

2 J. Muldoon, C. B. Bucur and T. Gregory, Chem. Rev., 2014, 114, 11683-11720.

3 P. Canepa, G. S. Gautam, D. C. Hannah, R. Malik, M. Liu, K. G. Gallagher, K. A. Persson and G. Ceder, Chem. Rev., 2017, 117, 4287-4341.

4 M. E. Arroyo-de Dompablo, A. Ponrouch, P. Johansson and M. R. Palacin, Chem. Rev., 2019, DOI: 10.1021/acs. chemrev.9b00339.

5 A. Ponrouch, C. Frontera, F. Barde and M. R. Palacin, Nat. Mater., 2015, 15, 169-172.

6 D. Wang, X. Gao, Y. Chen, L. Jin, C. Kuss and P. G. Bruce, Nat. Mater., 2018, 17, 16-20.

7 A. Shyamsunder, L. E. Blanc, A. Assoud and L. F. Nazar, ACS Energy Lett., 2019, 49, 2271-2276.

8 Z. Li, O. Fuhr, M. Fichtner and Z. Zhao-Karger, Energy Environ. Sci., 2019, 12, 3496-3501.

9 A. Ponrouch and M. R. Palacin, Curr. Opin. Electrochem., 2018, 9, 1-7.
10 R. J. Gummow, G. Vamvounis, M. B. Kannan and Y. He, Adv. Mater., 2018, 30, e1801702.

11 G. G. Amatucci, F. Badway, A. Singhal, B. Beaudoin, G. Skandan, T. Bowmer, I. Plitza, N. Pereira, T. Chapman and R. Jaworski, J. Electrochem. Soc., 2001, 148, A940-A950.

12 D. S. Tchitchekova, A. Ponrouch, R. Verrelli, T. Broux, C. Frontera, A. Sorrentino, F. Barde, N. Biskup, M. E. Arroyo-de Dompablo and M. R. Palacin, Chem. Mater., 2018, 30, 847-856.

13 M. Cabello, F. Nacimiento, R. Alcantara, P. Lavela, C. PérezVicente and J. L. Tirado, Chem. Mater., 2018, 30, 58535861.

14 M. Cabello, F. Nacimiento, J. R. González, G. Ortiz, R. Alcántara, P. Lavela, C. Pérez-Vicente and J. L. Tirado, Electrochem. Commun., 2016, 67, 59-64.

15 M. E. Arroyo-de Dompablo, C. Krich, J. Nava-Avendano, N. Biskup, M. R. Palacin and F. Barde, Chem. Mater., 2016, 28, 6886-6893.

16 M. E. Arroyo-de Dompablo, C. Krich, J. Nava-Avendaño, M. R. Palacín and F. Bardé, Phys. Chem. Chem. Phys., 2016, 18, 19966-19972.

17 R. Verrelli, A. P. Black, C. Pattanathummasid, D. S. Tchitchekova, A. Ponrouch, J. Oro-Sole, C. Frontera, F. Barde, P. Rozier and M. R. Palacin, J. Power Sources, 2018, 407, 162-172.

18 G. S. Gautam, P. Canepa, R. Malik, M. Liu, K. Perssonb and G. Ceder, Chem. Commun., 2015, 51, 13619-13622.

19 D. S. Tchitchekova, C. Frontera, A. Ponrouch, C. Krich, F. Barde and M. R. Palacin, Dalton Trans., 2018, 47, 1129811302.

20 A. Torres, F. Bardé and M. E. Arroyo-de Dompablo, Solid State Ionics, 2019, 340, 115004.

21 Z. Rong, R. Malik, P. Canepa, G. S. Gautam, M. Liu, A. Jain, K. Persson and G. Ceder, Chem. Mater., 2015, 27, 60166021.

22 M. Liu, Z. Rong, R. Malik, P. Canepa, A. Jain, G. Ceder and K. A. Persson, Energy Environ. Sci., 2015, 8, 964-974.

23 A. Torres, F. J. Luque, J. Tortajada and M. E. Arroyo-de Dompablo, Energy Storage Mater., 2019, 21, 354-360.

24 J. Hyoung, J. W. Heo and S.-T. Hong, J. Power Sources, 2018, 390, 127-133.

25 S. Suzuki, T. Kato, H. Kawabata and M. Miyayama, J. New Mater. Electrochem. Syst., 2016, 19, 51-55.

26 A. Torres, F. J. Luque, J. Tortajada and M. E. Arroyo-de Dompablo, Sci. Rep., 2019, 9, 9644.

27 E. F. Bertaut, P. Blum and G. Magnano, Acta Crystallogr., 1957, 10, 238-238.

28 B. F. Decker and J. S. Kasper, Acta Crystallogr., 1957, 10, 332-337.

29 B. Malaman, H. Alebouyeh, F. Jeannot, A. Courtois, R. Gerardin and O. Evrard, Mater. Res. Bull., 1981, 16, 1139-1148.

30 O. Evrard, B. Malaman, F. Jeannot, A. Courtois, H. Alebouyeh and R. Gerardin, J. Solid State Chem., 1980, 35, 112-119. 
31 B. Malaman, H. Alebouyeh, A. Courtois, R. Gerardin and O. Evrard, Mater. Res. Bull., 1982, 17, 795-800.

32 M. Aspiala, T. Hidayat, P. Taskinen and E. Jak, J. Alloys Compd., 2016, 658, 939-945.

33 H.-Y. Li and X.-M. Guo, Metall. Mater. Trans. B, 2015, 46, 278-285.

34 E. Rosen and B. Saitton, Scand. J. Metall., 1995, 24, 176179.

35 D. Morgan, A. Van der Ven and G. Ceder, Electrochem. Solid-State Lett., 2004, 7, A30-A32.

36 G. Kresse and J. Furthmuller, Phys. Rev. B: Condens. Matter Mater. Phys., 1996, 54, 11169-11186.

37 J. P. Perdew, K. Burke and M. Ernzerhof, Phys. Rev. Lett., 1996, 77, 3865-3868.

38 P. E. Bloch, Phys. Rev. B: Condens. Matter Mater. Phys., 1994, 50, 17953.

39 M. K. Aydinol, A. F. Kohan, G. Ceder, K. Cho and J. Joannopoulos, Phys. Rev. B: Condens. Matter Mater. Phys., 1997, 56, 1354-1365.

40 A. Torres and M. E. Arroyo-de Dompablo, J. Phys. Chem. C, 2018, 122, 9356-9362.
41 F. Fauth, I. Peral, C. Popescu and M. Knapp, Powder Diffr., 2013, 28, 360-370.

42 C. R. Fell, D. H. Lee, Y. S. Meng, J. M. Gallardo-Amores, E. Moran and M. E. Arroyo-de Dompablo, Energy Environ. Sci., 2012, 5, 6214-6224.

43 Y. S. Meng and M. E. Arroyo-de Dompablo, Energy Environ. Sci., 2009, 2, 589-609.

44 H. Yuan, H. Li, T. Zhang, G. Li, T. He, F. Du and S. Feng, J. Mater. Chem. A, 2018, 6, 8413-8418.

45 M. P. Pechini, US Pat, 3330697, 1967.

46 B. Mortemard de Boisse, M. Reynaud, J. Ma, J. Kikkawa, S.-i. Nishimura, M. Casas-Cabanas, C. Delmas, M. Okubo and A. Yamada, Nat. Commun., 2019, 10, 2185.

47 A. R. Wizansky, P. E. Rauch and F. J. Disalvo, J. Solid State Chem., 1989, 81, 203-207.

48 D. Larcher, D. Bonnin, R. Cortes, I. Rivals, L. Personnaz and J.-M. Tarascon, J. Electrochem. Soc., 2003, 150, A1643A1650.

49 J. M. Tarascon, S. Grugeon, S. Laruelle, D. Larcher and P. Poizot, in Lithium Batteries: Science and Technology, ed. G. Nazri and G. Pistoia, Kluwer Academic Publishers, 2004. 